\title{
Kemoterapi Alan Onkoloji Hastalarında Yaşam Biçimi Davranışları, Besin Tüketim Sıklıkları ve Riskli Beslenme Alışkanlıkları
}

\author{
Lifestyle Behaviors, Food Consumption Frequencies and Risky Nutritional Habits in Oncology \\ Patients Receiving Chemotherapy
}

\section{Derya Hopancı Bıçaklı1, Medine Yılmaz²}

Geliş tarihi/Received: 19.10.2018 • Kabul tarihi/Accepted: 25.11.2018

\section{ÖZET}

Amaç: Kanserin hem oluşumu hem de tekrar etmesinde kontrol edilebilir bir risk etmeni olan bireysel yaşam tarzının önemi büyüktür. Bu çalışmanın amacı medikal onkoloji polikliniğinde kanser tanısıyla izlenen ve kemoterapi alan hastaların yaşam biçim davranışları ile besin tüketim çeşitlilikleri, sıklıkları ve riskli beslenme alışkanlıklarının incelenmesidir.

Bireyler ve Yöntem: Tanımlayıcı ve karşılaştırmalı tipteki bu araştırma, hastanemizin onkoloji polikliniğinde izlenen olasıllısız örneklem yöntemi ile araştırmaya katılmaya gönüllü 259 kanser hastası (yaş ortalaması 52.1 yll, \%64.5’i kadın, \%35.5’i erkek) ile yürütülmüştür. Araştırmada "Yaşam Biçimi Aktiviteleri ve Riskli Beslenme Alışkanlıkları Anketi” kullanılmıştır. Besin tüketim sıklıkları "hiç”, “ nadir”, "haftada bir” ve "her gün” olarak sınıflandırılmıştır. Wilcoxon testi kullanılmış ve $\mathrm{p}<0.05$ istatistiksel olarak anlamlı kabul edilmiştir.

Bulgular: Hastaların \%50.6’sının egzersiz yapmadığı, \%33.2'sinin obez olduğu, \%55.6’sının da sağlığını kötü olarak algıladığı saptanmıştır. Hastaların \%19.7’sinin fitoterapi, \%19.3’ünün vitamin kullandığı ve kullananların \%47.6’sının doktor/hemşire/ diyetisyene danışmadan kullandığı görülmüştür. Hastaların kanser tanısı sonrasında tavuk eti, sosis-salam, sucuk, süt, kahve, çay, meşrubat, şeker ve bisküvi, diğer yağların (tereyağı, margarin, ayçiçek yağı) tüketim sıklığının azaldığı (p<0.05), zeytinyağı tüketim sıklığının arttığı $(\mathrm{p}<0.05)$ belirlenmiştir.

Sonuç: Çalışma bulguları kanser hastalarının beslenme durumunun belirlenerek sağlıklı yaşam biçimi kazandırmanın gerekliliğini ve riskli besinlerin tüketim sıklı̆̆ının azaltılması konusunda eğitim verilmesinin önemini ortaya çıkarmıştır. Kanser tedavisi sırası ve sonrasında hastalar, yaşam biçimi alışkanlıkları ve beslenmeleri yönünden düzenli olarak izlenmelidir.

Anahtar kelimeler: Beslenme, onkoloji, kemoterapi, yaşam biçimi davranışları

\section{ABSTRACT}

Aim: The individual lifestyle, which is a controllable risk factor in both at the development and recurrence of cancer, is of great importance. The aim of this study was to investigate the lifestyle behaviors, dietary consumption, frequency and risky dietary habits of the patients who were followed up with the diagnosis of cancer in the medical oncology outpatient clinic.

Subjects and Method: This descriptive and comparative study was carried out on 259 cancer patients (mean age 52.1 years, $64.5 \%$ female, $35.5 \%$ male) who were volunteered to participate in the study with the probabilistic sampling method in the oncology outpatient clinic of our hospital. "Lifestyle Activities and Risky Eating Habits Questionnaire" was used in the study.

1. İletişim/Correspondence: Ege Üniversitesi, Tip Fakültesi Hastanesi, Medikal Onkoloji Bilim Dal, İzmir, Türkiye • E-posta: deryahopanci@hotmail.com (ㄱ) https://orcid.org/0000-0003-1594-3266
2. ̇̇zmir Kâtip Çelebi Üniversitesi Hemşirelik Fakültesi, Halk Sağlığı Hemşireliği Bilim Dall, İzmir, Türkiye

๑ https://orcid.org/0000-0001-9409-6282 
Food consumption frequencies were classified as "none, rare, once a week and every day". Wilcoxon test was used and a value of $p<0.05$ was considered as statistically significant.

Results: It was determined that $50.6 \%$ of patients did not exercise, $33.2 \%$ were obese and $55.6 \%$ perceived their health as bad. The frequency of phytotherapy and vitamin supplement use were $19.7 \%$ and $19.3 \%$, respectively, and $47.6 \%$ of patients reported that they use these supplements without any consultation of their doctors/nurses/dietitians. Patients decreased the frequency of consumption of foods such as chicken, sausages-salami, Turkish sausage, milk, coffee, tea, soft drinks, sugar and biscuits, fats (butter, margarine, sunflower seed oil), and increased the frequency of olive oil consumption after they were diagnosed with cancer $(\mathrm{p}<0.05)$.

Conclusion: The findings of this study revealed the importance of providing of a healthy lifestyle accompanied with the evaluation of nutritional status, and giving education to cancer patients on reducing the consumption of risky foods.

Keywords: Nutrition, oncology, chemotherapy, healthy lifestyle

\section{Gíriş}

Kanser kronik bir sağlık sorunu olarak çeşitli komplikasyonları beraberinde getirmekte, bu komplikasyonlara bağlı yetersizliğe/engelliliğe, işgücü kaybına neden olmaktadır. Kanserin bölgeler/ ülkeler arası farklılık göstermesinin bireylerin tükettikleri besinler ve yaşam biçimleri gibi nedenlere bağlı olarak gelişebildiği bilinmektedir (1-3). Epidemiyolojik araştırmalar yaşam biçimi davranışlarının kanser oluşumunda önemli bir etkiye sahip olduğunu göstermektedir (4). Tüm kanserlerin \%85’inin yaşam tarzı ile ilişkili olduğu ve kontrol edilebilir bireysel alışkanlıklardan kaynaklandığı bildirilmektedir (5). Tütün ve alkol kullanımı, sedanter yaşam tarzı, obezite, kırmızı et, tuzlu ve tütsülenmiş besin tüketiminin fazla olması, besinlere uygulanan yanlış hazırlama, pişirme ve saklama yöntemleri kanser oluşumu açısından risk oluşturabilmektedir (6-9). Bununla birlikte kanser tedavisi sırasinda ve sonrasinda, kanser nüksü, sekonder tümörlerin gelişimi ve kardiyovasküler hastalıklar açısından da risk oluşturmaya devam etmektedir $(4,10,11)$.

Literatürde kanserin önlenmesinde sağlıklı yaşam biçimi davranışlarının önemini (11-13), kanserden iyileşmiş hastalarda beslenmenin ve fiziksel aktivitenin önemi ile davranış değişimine yönelik girişimlerin etkisini inceleyen çalışmalar (14-16) ve sistematik derlemeler (17-19) olduğu görülmektedir. Buna karşılık kanser tedavisi aktif olarak devam eden hastalarda yaşam biçimi davranışları, besin tüketim çeşitliliği ve sıklığı ile ilgili çalışmaların sınırlı olduğu görülmüştür (20).

Bu çalışmanın amacı, medikal onkoloji polikliniğinde kanser tanısıyla izlenen ve kemoterapi alan hastaların yaşam biçim davranışları ile besin tüketim sıklıkları ve riskli beslenme alışkanlıklarının incelenmesidir. $\mathrm{Bu}$ araştırma bulgularının kanserli hastalara tedavileri sırasında ve sonrasında önerilecek yaşam biçimi alışkanlıklarına ilişkin eğitimler/girişimlere yol gösterici olacağı düşünülmektedir. Bu doğrultuda araştırma soruları şunlardır: Kemoterapi alan hastaların "Sağlıklı yaşam biçimi davranışları ve riskli beslenme alışkanlıkları nelerdir?” ve “Tanı öncesi ve tanı sonrası besin tüketim çeşitlilikleri ve sıklıkları arasında fark var mıdır?”.

\section{BİREYLER VE YÖNTEM}

\section{Araştırma Yeri ve Örneklemi}

Tanımlayıcı ve karşılaştırılmalı tipteki bu araştırma Ege Üniversitesi Hastanesi Medikal Onkoloji polikliniğinde yürütülmüştür. Araştırmanın örneklemi \%95 güven aralığında, \%5 hata payı ile 256 hasta olarak belirlenmiştir. Kanser tanısı ile medikal onkoloji polikliniğinde kemoterapi tedavisi gören, genel durumu kötü olmayan, işitme ve konuşma 
sorunu olmayan ve araştırmaya katılmayı kabul eden, 18 yaş ve üzeri hastalar araştırmaya alınmıştır. Relaps ve terminal dönemde olan, kemoterapi aldığı sırada kendini iyi hissetmeyen hastalar araştırmaya alınmamıştır. Ayrıca bu araştırmadan bağımsız olarak kliniğin rutin uygulaması gereği, tüm hastalar tanı aldığı andan itibaren araştırmacı olan diyetisyen tarafından standart eğitime tabi tutulmaktadır.

Ege Üniversitesi girişimsel olmayan araştırmalar etik kurulundan etik izin (26.02.2013 /no:131.1/15) alınmıştır. Her hastadan görüşme öncesi bilgilendirilmiş gönüllü olur izni alınmıştır.

\section{Veri Toplama}

Araştırmada literatür (2,3,21-25) doğrultusunda hazırlanan ve uzman görüşü (diyetisyen, onkoloji hemşiresi ve doktor) alınan "Yaşam Biçimi ve Beslenme Alışkanlıklarını Belirleme Formu” kullanılmıştır. Formda sosyo-demografikve sağlık/hastalıközelliklere ilişkin soruların (20 soru) yanı sıra farklı kanser tipleri için risk oluşturabilecek yaşam biçimi davranışlarına yönelik sorular (11 soru) da yer almıştır. Ayrıca besin hazırlama ve saklama koşullarına ilişkin (21 soru) sorular sorulmuştur. Hastaların boy uzunluğu (cm) ile vücut ağırlığı (kg) ölçümleri baskül ve stadiometre ile yapılmıştır. Vücut ağırlığının, boy uzunluğunun metrekaresine bölünmesi [vücut ağırlığı $(\mathrm{kg}) / \mathrm{boy}\left(\mathrm{m}^{2}\right)$ ] ile bireylerin beden kütle indeksleri (BKİ) hesaplanmış ve Dünya Sağlık Örgütü (WHO) sinıflamasına göre değerlendirilmiştir (26).

\section{Verilerin İstatistiksel Değerlendirmesi}

İstatistiksel analizler SPSS 22.0 paket programinda yapılmıştır. Verilerin analizinde sayı (n) ve yüzde (\%) dağılımları kullanılmıştır. Besin tüketim sıklıklarının tanı öncesi ve sonrası dağılım farklarını belirlemek için Wilcoxon analizi kullanılmıştır. İstatistiksel analiz için ayda bir ve 15 günde bir tüketenler bir grupta, her gün ve haftada 3-4 kez tüketenler diğer grupta değerlendirilmiştir. İstatistik olarak $\mathrm{p}<0.05$ anlamlı kabul edilmiştir.

\section{BULGULAR}

Çalışmada değerlendirilen 259 hastanın ortanca yaşı 52.1 yll (18-83 yll), \%64.1'i kadın, \%35.5'i erkektir. Araştırmaya katılan hastaların \%51.0'i ilköğretim mezunudur. Hastaların \%48.5’i sedanter bir iş yapmış/ yapmaktadır. Hastaların demografik özellikleri Tablo 1'de gösterilmiştir.

Tablo 1. Bireylerin demografik özelliklerine göre dağılımı $(\mathrm{n}=259)$

\begin{tabular}{lcc}
\hline Özellikler & n & \% \\
\hline Cinsiyet & & \\
$\quad$ Kadın & 167 & 64.5 \\
$\quad$ Erkek & 92 & 35.5 \\
Eğitim durumu & & \\
$\quad$ Okur-yazar değil & 15 & 5.8 \\
$\quad$ Ilk-orta öğretim & 132 & 51.0 \\
$\quad$ Lise & 64 & 24.7 \\
$\quad$ Yüksekokul/fakülte & 48 & 18.5 \\
Çalışma aktivitesi* & & \\
$\quad$ Aktif & 118 & 51.5 \\
$\quad$ Sedanter & 111 & 48.5 \\
Gelir gider durumu & & \\
$\quad$ Geliri giderinden az & 69 & 26.6 \\
$\quad$ Geliri giderine eşit & 152 & 58.7 \\
$\quad$ Geliri giderinden fazla & 38 & 14.7 \\
\hline${ }^{*}=229$
\end{tabular}

Hastaların sağllk ve hastalık özelliklerine ilişkin bulguları Tablo 2'de gösterilmiştir. Buna göre hastaların \%34.4'ünün ağız diş sağlığı sorunu olduğu, \%19.3’ünün halen alkol kullandığı, \%50.6’sının egzersiz yapmadığı, sadece \%25.5’inin düzenli egzersiz yaptığı belirlenmiştir. Beden kütle indeksleri (BKİ) değerlendirildiğinde \%34.0’ü kiloludur. Bireylerin \%55.6’sı ise sağlığını kötü olarak algılamaktadır (Tablo 2).

Hastaların riskli besin tüketim özellikleri ve fitoterapi/vitamin kullanma durumlarının dağılımı Tablo 3’te gösterilmiştir. Buna göre, hastaların \%19.7'sinin fitoterapi kullandığı, kullananların da \%47.6’sının sağlık çalışanlarına danışmadan kullandığı belirlenmiştir. Hastaların \%19.3’ü vitamin kullandığını belirtmiştir. Hastaların \%31.7'si yemeklere tuz eklemektedir, \%42.1’i beyaz ekmek tüketmektedir (Tablo 3). 
Tablo 2. Sağlık ve hastalık özelliklerine ilişkin bulgularının dağılımı ( $\mathrm{n}=259)$

\begin{tabular}{|c|c|c|}
\hline Özellikler & $\mathbf{n}$ & $\%$ \\
\hline \multicolumn{3}{|l|}{ Kanser tipi } \\
\hline Meme & 69 & 26.7 \\
\hline Kolon & 55 & 21.2 \\
\hline Over & 16 & 6.2 \\
\hline Mide & 16 & 6.2 \\
\hline Diğer & 103 & 39.7 \\
\hline \multicolumn{3}{|l|}{ Ailede kanser öyküsü } \\
\hline Var & 142 & 54.8 \\
\hline \multicolumn{3}{|l|}{ Kronik hastalık varlığı } \\
\hline Var & 79 & 30.5 \\
\hline \multicolumn{3}{|l|}{ Ağız-diş sağlığı sorunu } \\
\hline Var & 89 & 34.4 \\
\hline \multicolumn{3}{|l|}{ Sigara içme durumu } \\
\hline Halen içiyor & 16 & 6.2 \\
\hline Birakmış & 117 & 45.2 \\
\hline Hiç içmemiş & 126 & 48.6 \\
\hline \multicolumn{3}{|l|}{ Alkol kullanma durumu } \\
\hline Halen kullanıyor & 50 & 19.3 \\
\hline Bırakmış & 26 & 10.0 \\
\hline Hiç kullanmamış & 183 & 70.7 \\
\hline \multicolumn{3}{|l|}{ Egzersiz yapma } \\
\hline Yapmiyor & 131 & 50.6 \\
\hline Ara sira & 62 & 23.9 \\
\hline Düzenli & 66 & 25.5 \\
\hline \multicolumn{3}{|l|}{ BKİ sınıflaması* } \\
\hline$<18.5$ kg/m² (Zaylf) & 14 & 5.5 \\
\hline $18.5-24.99 \mathrm{~kg} / \mathrm{m}^{2}$ (Normal) & 117 & 45.2 \\
\hline $25-29.99$ kg/m² (Kilolu) & 86 & 34.0 \\
\hline 30 kg/m² ve üzeri (Şişman) & 42 & 16.6 \\
\hline \multicolumn{3}{|l|}{ Sağlığı algılama } \\
\hline Çok kötü & 41 & 15.8 \\
\hline Kötü & 144 & 55.6 \\
\hline Orta & 33 & 12.7 \\
\hline İyi & 41 & 15.8 \\
\hline
\end{tabular}

*BKİ: Beden kütle indeksi
Tablo 3. Hastaların riskli besin tüketim özellikleri ve fitoterapi/vitamin kullanma durumlarının dağılımı $(n=259)$

\begin{tabular}{|c|c|c|}
\hline Besin tüketim özellikleri & $\mathbf{n}$ & $\%$ \\
\hline \multicolumn{3}{|l|}{ Fitoterapi kullanımı } \\
\hline Kullanmiyor & 208 & 80.3 \\
\hline Kullanıyor & 51 & 19.7 \\
\hline \multicolumn{3}{|l|}{ Doktorla paylaşma durumu } \\
\hline Paylaşmamış & 24 & 47.6 \\
\hline Paylaşmış & 27 & 10.4 \\
\hline \multicolumn{3}{|l|}{ Vitamin kullanımı } \\
\hline Kullanıyor & 50 & 19.3 \\
\hline Kullanmiyor & 208 & 80.7 \\
\hline \multicolumn{3}{|l|}{ Salamura besin tüketimi } \\
\hline Tüketmiyor & 100 & 38.6 \\
\hline Tüketiyor & 159 & 61.4 \\
\hline \multicolumn{3}{|l|}{ Acı biber tüketimi } \\
\hline Tüketmiyor & 132 & 51.0 \\
\hline Tüketiyor & 127 & 49.0 \\
\hline \multicolumn{3}{|l|}{ Mangalda et tüketimi } \\
\hline Tüketmiyor & 86 & 33.2 \\
\hline Tüketiyor & 173 & 66.8 \\
\hline \multicolumn{3}{|l|}{ Yanmış besin tüketimi } \\
\hline Tüketmiyor & 148 & 57.2 \\
\hline Tüketiyor & 111 & 42.9 \\
\hline \multicolumn{3}{|l|}{ Sıcak içecek tüketimi } \\
\hline Tüketmiyor & 138 & 53.3 \\
\hline Tüketiyor & 121 & 46.7 \\
\hline \multicolumn{3}{|l|}{ Şeker ekleme } \\
\hline Hayır & 116 & 44.8 \\
\hline Evet & 143 & 55.2 \\
\hline \multicolumn{3}{|l|}{ Sofra tuzu ekleme } \\
\hline Hayır & 177 & 68.4 \\
\hline Evet & 82 & 31.7 \\
\hline \multicolumn{3}{|l|}{ Ekmek tipi tercihi } \\
\hline Beyaz ekmek & 109 & 42.1 \\
\hline Çok tahıllı & 69 & 26.6 \\
\hline Kepekli & 48 & 18.5 \\
\hline Diğer & 35 & 12.7 \\
\hline
\end{tabular}

Hastaların besin hazırlama ve saklama haşlama suyunu dökmekte, \%39.8’i sebzeleri kavurarak pişirmektedir. Hastaların \%43.2'si beslenmenin kanser ile ilişkili olduğuna ve \%38.6'sı obezitenin kanser ile ilişkili olduğuna inanmaktadır (Tablo 4). 
Tablo 4. Besin hazırlama ve saklama koşullarına ilişkin bulgular $(n=259)$

\begin{tabular}{|c|c|c|}
\hline Uygulamalar & $\mathbf{n}$ & $\%$ \\
\hline \multicolumn{3}{|l|}{ Kızartma tüketimi } \\
\hline Hiç tüketmiyor & 95 & 36.7 \\
\hline Tüketiyor & 164 & 63.3 \\
\hline \multicolumn{3}{|l|}{ Kızartma yağı kullanım sayısı } \\
\hline $1 \mathrm{kez}$ & 210 & 81.1 \\
\hline 2 ve üzeri & 49 & 18.9 \\
\hline \multicolumn{3}{|c|}{ Kurubaklagillerin haşlama suyunu dökme } \\
\hline Dökmeyen & 100 & 38.6 \\
\hline Döken & 159 & 61.4 \\
\hline \multicolumn{3}{|l|}{ Sebze pişirme } \\
\hline Çiğden & 142 & 53.8 \\
\hline Kavurarak & 103 & 39.8 \\
\hline Her ikisi de & 14 & 5.4 \\
\hline \multicolumn{3}{|l|}{ Kışlık besin saklama şekli* } \\
\hline Konserve & 35 & 14.6 \\
\hline Kurutma & 30 & 11.6 \\
\hline Dondurma & 106 & 44.2 \\
\hline Karışık & 69 & 28.7 \\
\hline \multicolumn{3}{|l|}{ Mikrodalga kullanımı } \\
\hline Hayır & 201 & 77.6 \\
\hline Evet & 58 & 22.4 \\
\hline \multicolumn{3}{|l|}{ Küflü besin tüketimi } \\
\hline Hayır & 248 & 95.8 \\
\hline Evet & 11 & 4.2 \\
\hline \multicolumn{3}{|l|}{ Baharat kullanımı } \\
\hline Tazeliğine dikkat etmeyen & 69 & 26.6 \\
\hline Tazeliğine dikkat eden & 188 & 72.6 \\
\hline \multicolumn{3}{|c|}{ Beslenme ve kanser ilişkisine inanma } \\
\hline Hayır & 81 & 31.3 \\
\hline Evet & 112 & 43.2 \\
\hline Emin değil & 66 & 25.5 \\
\hline \multicolumn{3}{|c|}{ Obezite ve kanser ilişkisine inanma } \\
\hline Hayır & 86 & 33.2 \\
\hline Evet & 100 & 38.6 \\
\hline Emin değil & 73 & 28.2 \\
\hline
\end{tabular}

${ }^{*} n=240$

Bireylerin besin gruplarına göre tanı öncesi ve sonrası tüketim sıklıkları Tablo 5’te görülmektedir. Tavuk, hindi, salam, sosis, tereyağı, margarin, ayçiçek yağı, çay, kahve, şeker, meşrubat, bisküvi, gofret tüketim sıklığı anlamlı düzeyde azalmıştır $(\mathrm{p}<0.01)$. Tanıdan sonra hiç süt ürünü tüketmeyenlerin sıklığında artış olduğu görülmüştür $(p<0.05)$. Tanı öncesine göre her gün zeytinyağı tüketenlerin sıklığı artarken, diğer yağlar (tereyağı, margarin, ayçiçek yağı) açısından her gün tüketenlerin sıklığı azalmıştır $(p<0.05)$. Benzer şekilde hastaların tanıdan sonra su tüketim miktarlarının $1.5 \mathrm{~L}$ ve üzerine çıktığı belirlenmiştir $(\mathrm{p}<0.05)$.

\section{TARTIŞMA}

Kanser, küresel ve büyüyen bir sorundur. Sadece demografik değişim değil, aynı zamanda yaşam biçimine ilişkin artan risk etmenleri de mevcut kanser yüküne katkıda bulunmaktadır (27). Medikal onkoloji polikliniğinde kanser tanısıyla izlenen ve kemoterapi alan hastaların yaşam biçim davranışları ile besin tüketim çeşitlilikleri, sıklıkları ve riskli beslenme alışkanlıklarının incelendiği bu çalışmada hastaların kanser tanısından önce beyaz ekmek, şeker ve katı yağ, kızartma, salamura, mangalda et tüketimlerinin fazla, beyaz et ve su tüketimlerinin az olduğu saptanmıştır. Her iki hastadan birisinin sigara içtiği/bıraktığı ve egzersiz yapmadığı belirlenmiştir. Bununla birlikte tanı sonrası tükettikleri besin çeşitliliği ve sıklığının da değiştiği görülmüştür.

Fiziksel aktivitenin yaşam kalitesini olumlu etkilediği ve tedaviyi tamamlamış kanser hastalarının yönetim planlarına entegre edilebileceği belirtilmektedir $(11,28)$. Fiziksel aktivite yetersizliğinin sarkopeni nedenlerinden biri olduğu, bu durumun post-operatif komplikasyonlar, kemoterapi kaynaklı toksisite ve sağ-kalımın azalması ile anlamlı ilişki içinde olduğu belirtilmiştir (29). Fiziksel aktivite yetersizliğinin meme kanseri vakalarının \%9'una ve kolon kanseri vakalarının \%10'una neden olduğu düşünülmektedir (11). Bu çalışmada hastaların yarısının fiziksel aktivite yapmadığı sadece dört hastadan birisinin düzenli egzersiz yaptığı saptanmıştır. Fiziksel aktivite yapma oranının düşük olması hastaların daha çok 65 yaş ve üzeri grupta olması ile ilişkili olabilir. Avrupa Parenteral ve Enteral Beslenme Derneği (European Society For Clinical Nutrition and Metabolism- 


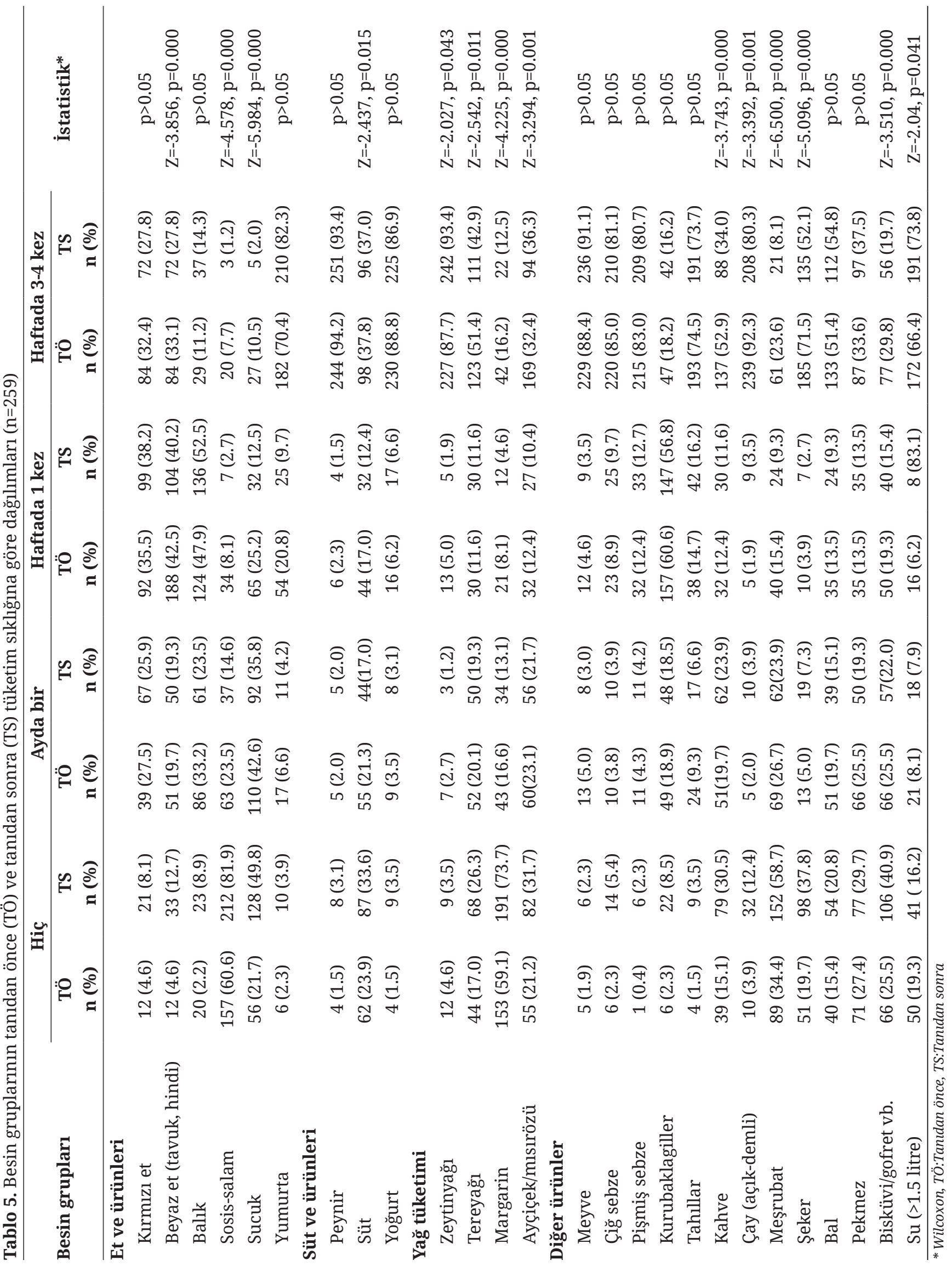


ESPEN)-2017 önerilerinde fiziksel aktiviteyi arttırmaya odaklanan, bireyselleştirilmiş beslenme müdahalelerini önermiştir (30). Bu durumda hastalar, tanıdan itibaren bireysel özelliklerine uygun fiziksel aktivitelerini arttırmaları ve durumlarına uygun egzersiz programlarına katılmaları konusunda teşvik edilmelidir.

Vücut ağırlığı denetimi kanser açısından önem taşımaktadır (21). Obezite, endometrium, hepatoselüler ve postmenopozal meme kanserinde risk artışının anahtar etmenidir $(23,31)$. Bu çalışmada hastaların yaklaşık yarısının kilolu ve obez olduğu saptanmıştır. Dikkat çeken bir diğer nokta ise hastaların \%38.6'sının obezite ile kanser arasında pozitif bir ilişki olduğuna inanmalarıdır.

Alkollü içecek tüketiminin birçok kanser türünün oluşum riskini arttırdığı bilinmektedir (12). Premalign ve invaziv meme kanseri için en tutarlı diyet risk etmeninin alkol olduğu bildirilmektedir $(23,32)$. Bu çalışmada da yaklaşık beş hastadan birisinin halen alkol kullandığı belirlenmiştir. Bu yönüyle hastalara alkolün kanser ile ilişkisi yönünde farkındalıkları arttırılarak, alkol bırakma terapilerine yönlendirmek yararlı olacaktır.

Aşırı tuzlu veya salamura besinlerin fazla miktarlarda tüketimi özofagus ve mide kanseri riskini, aşırı sıcak içecek tüketimi ise ağız boşluğu, farinks ve özofagus kanseri riskini arttırmaktadır (22). Bu araştırma sonuçları hastaların salamura besin tüketmeleri ve tuz eklenmesi uygulamaları, mangalda pişmiş besinler ile aşırı sıcak ve şekerli içecekler tüketmeleri, diyetlerinin posa içeriğinin düşük olması gibi riskli beslenme alışkanlıklarına sahip olduklarını göstermiştir. Bu durum geleneksel kültürel beslenme alışkanlıklarının etkisini yansıtmaktadır. Ayrıca bu araştırmada hastaların yarıdan fazlasının pişirme yöntemi olarak kızartmayı ve beşte birinin kızartma yağını birden çok kez kullandıkları, kuru baklagillerin haşlama suyunu dökmek gibi vitamin kayıplarına neden olan olumsuz pişirme tekniklerini uyguladıkları görülmüştür. Heterosiklik aminler ve polisiklik aromatik hidrokarbonlar olarak bilinen karsinojenik bileşikler balık, tavuk etinin ve protein içeren diğer besinlerin yüksek sıcaklıklarda kızartılması ile oluşmaktadır (33). Kızartma yöntemi ile beslenmenin prostat, pankreas, akciğer, oral/ faringeal, özofagus ve laringeal kanserler ile ilişkili olduğu bilinmektedir (34). Bu konudaki hasta bakış açısı değerlendirildiğinde hastaların \%43’ünün beslenme ile kanser arasında doğrudan ilişki olduğuna inandığı belirlenmiştir. İnandıkları konu ile ilgili olarak davranış değişikliğine gidilmesi konusunda eğitim verilmesi önemlidir.

Kanser hastaları arasinda tamamlayıcı alternatif tedavi uygulayanların oranı \%77'yi bulmaktadır (35). Bu çalışmada ise her beş hastadan birisinin fitoterapi kullandığı bulunmuştur. $\mathrm{Bu}$ noktada önemsenmesi gereken durumlardan biri hastaların sağlık çalışanlarına danışmadan fitoterapi kullanmalarıdır. Bazı bitki ve meyvelerin içerdiği flavonoidler ilaç metabolizmasına katılan sitokrom P450, p-glikoproteinler ve Faz-II enzimlerin etkinliğini değiştirebilirler (36). Bu çalışmada hastaların yaklaşık beşte birinin diyete ek olarak vitamin kullandığ belirlenmiştir. Kanser hastalarında vitamin ve mineral miktarlarının günlük alım önerilerine göre sağlanması ve anlamlı eksiklikler yoksa yüksek doz mikro besin ögesi desteklerinden kaçınılması gerektiği belirtilmektedir (37).

Dünya Kanser Araştırma Fonu'nun Beslenme, Fiziksel Aktivite ve Kanser Önleme Önerileri’nde kırmızı ve işlenmiş etten kaçınma, alkollü içecekleri ve tuz tüketimini sınırlama önerilerine yer verilmiştir (25). Meyve, sebze ve tam tahılll, kepekli besinlerin yüksek alıminı öneren diyet modellerinin kanser riskini azalttığı belirtilmiştir $(13,23)$. Bu çalışmada her gün çiğ ve pişmiş sebze ve meyve tüketenlerin oranının sevindirici şekilde yüksek olduğu, tanıdan sonra bu oranların değişmediği görülmüştür. Kolorektal kanserli hastaların \%10'undan daha azının günde beş porsiyon sebze-meyve tükettiği belirlenmiştir (38). Hastalara tanıdan itibaren sağlıklı beslenme konularında eğitim ve danışmanlık yapılması hem tedavi sürecinin daha konforlu geçirilmesi hem de tedavi sonrası nüksün önlenmesi açısından yararlı olacaktır. 
Kanser tedavisi sirasında yeterli protein alımını karşılamakiçin eniyiseçenek, doymuşyağıaz miktarda içeren besinlerdir (25). Bu araştırmada hastaların tanı öncesi ve sonrası kırmızı et tüketim sıklıklarının değişmediği, beyaz et tüketim sıklıklarının azaldığı belirlenmiştir. Bununla birlikte hem tanı öncesi hem tanı sonrasında hastaların önemli bir bölümünün kurubaklagilleri sık tükettiği, düzenli yoğurt ve peynir tüketimlerinin olduğu, işlenmiş et ürünleri (sosis, salam, sucuk) tüketimlerini azalttıkları, riskli bazı besinleri diyetten çıkarmış olmaları sevindiricidir. Hastaların tanıdan sonra günde >1.5 litre su içme sıklığı artmış olsa da bu oran onkoloji hastaları için yeterli bulunmamıştır. Bununla birlikte hiç su içmeyen hasta oranı da azımsanamayacak düzeyde çoktur. Hastaların tanıdan sonra tereyağı, şeker, çay, kahve, meşrubat tüketim sıklığı azalmış, zeytinyağı tüketim sıklığı artmıştır. Bu olumlu değişikliklerin hasta ve hasta yakınlarının beslenmeye karşı artan ilgisinin yanı sıra tanı anında aldıkları rutin sağlıklı beslenme eğitimi ve diyet danışmanlığının etkisi olabileceği düşünülmüştür. Amerika'da yapılan bir çalışmada kanser tanısından sonra hastaların \%66.3'ünün yaşam tarzı değişiklikleri yaptı̆̆ı, \%40.4’ünün bir veya daha fazla diyet değişikliği yaptığı, \%20.8'inin yeni bir fiziksel aktiviteye başladığı belirtilmiştir (39). Kanser tiplerine özgü sağlıklı yaşam biçimi ve beslenme davranışları girişimlerin etkinliğini gösterecek uzunlamasına çalışmalar planlanmalıdır.

$\mathrm{Bu}$ çalışmanın bazı kısıtlılıkları bulunmaktadır. Bunlardan ilki, hastaların tanı öncesi dönemdeki uygulamaları subjektif yanıtları içerecek şekilde soru yanıt yoluyla elde edilmiş olup hastaların geçmişi hatırlamalarıyla yakından ilişkili olmasıdır. Bu durumun araştırma bulgularını etkileyebileceği göz önünde bulundurulmalıdır. Çalışma örnekleminin yaş aralığının 18-83 yıl arasında değişim göstermesi, yaşın hem fiziksel aktivite düzeyi ve sağlık özellikleri hem de besin tüketim sıklığını etkileyebilecek önemli bir değişken olacağı göz önünde bulundurulmalıdır. Çalışmaya bir kontrol grubu alınmamış olması nedeniyle elde edilen sonuçların sağlıklı toplumun genelinden farklı olup olmadığı yorumlanamamıştır.
Hastalara uygulanan anket hazırlanırken besin çeşitleri ve tüketim sıklıkları sorgulanmıştır. Sonraki çalışmalar da bunlara ek olarak miktarların da sorgulanması daha kapsamlı bilgi verebilir.

Sonuç olarak kanser hastalarının sağlıklı yaşam biçimi alışkanlıkları, besin tüketim çeşitlilikleri ve sıklıklarının hem hastalığın oluşumunda hem de tedavi süreçlerinde büyük önemi vardır. Kanseri önleme çalışmalarında riskli beslenme alışkanlıklarının hastalığı başlatan süreçlere katkısı olduğu sağlıklı popülasyona anlatılmalı ve konuyla ilgili ülke politikaları geliştirilmelidir. Hastaların tanı öncesi ve sonrası süreçlerdeki beslenme davranış değişikliklerinin iyi yönetilebilmesi için tüm kanser hastalarıonkolojiktedaviile paralelilerleyen beslenme eğitimlerine alınmalı ve düzenli aralıklarla dikkatle izlenmelidir. Sağlıklı yaşam biçimi davranışlarının kazanılması, kanser açısından riskli besinlerin tüketilmesi ve hazırlanma şekillerinin değiştirilmesi, tedavi sürecinde olduğu kadar hastalıksız sağ-kalımda da önemli noktalardan biridir.

Çıkar çatışması - Conflict of interest: Yazarlar çıkar çatışması olmadığını beyan ederler. - The authors declare that they have no conflict of interest.

\section{KAYNAKLAR}

1. Jemal A, Bray F, Center MM. Global cancer statistics. CA Cancer J Clin 2011;61:69-90.

2. Fu Z, Shrubsole MJ, Smalley WE, Wu H, Chen Z, Shyr $\mathrm{Y}$, et al. Lifestyle factors and their combined impact on the risk of colorectal polyps. Am J Epidemiol 2012;176(9):766-76.

3. De Stefani E, Deneo-Pellegrini H, Ronco AL, Boffetta P, Correa P, Aune D. Meat consumption, cooking methods, mutagens, and risk of squamous cell carcinoma of the esophagus: A case-control study in Uruguay. Nutr Cancer 2012;64(2):294-9.

4. Meyerhardt JA, Niedzwiecki D, Hollis D, Saltz LB, Hu FB, Mayer RJ, et al. Association of dietary patterns with cancer recurrence and survival in patients with stage III colon cancer. JAMA; 298(7):754-64.

5. Barclay V. Basic Concepts in Cancer Nursing. Platin N, editor. 1st ed. Ankara, Turkey, Turkish Association for Cancer Research and Control; 1987. p. 11-36.

6. Chan AT, Giovannucci EL. Primary prevention of 
colorectal cancer. Gastroenterology 2010;138(6):202943.

7. Yıldız E. Kanser ve Beslenme. T.C. Sağlık Bakanlığı Yayınları. Erişim: https//sbu.saglik.gov.tr/Ekutuphane/ kitaplar/t58.pdf Erişim Tarihi: 2.12.2018.

8. Parsa P, Parsa B. Effects of reproductive factors on risk of breast cancer: a literature review. Asian Pac J Cancer Prev 2009;10(4):545-50.

9. Arafa MA, Waly MI, Jriesat S, Al Khafajei A, Sallam S. Dietary and lifestyle characteristics of colorectal cancer in Jordan: a case-control study. Asian Pac J Cancer Prev 2011;12(8):1931-6.

10. Kenfield SA, Van Blarigan EL, Stampfer MJ, Chan JM. Diet and exercise in cancer: Epidemiologic perspectives on optimizing survivorship via lifestyle. J Cancer Policy 2018;17:30-3.

11. Leitzmann M, Powers H, Anderson AS, Scoccianti C, Berrino F, Boutron-Ruault MC, et al. European Code against Cancer 4th Edition: Physical activity and cancer. Cancer Epidemiol 2015;39(Suppl 1):46-55.

12. Latino-Martel P, Cottet V, Druesne-Pecollo N, Pierre FH, Touillaud M, Touvier M, et al. Alcoholic beverages, obesity, physical activity and other nutritional factors, and cancer risk: A review of the evidence. Crit Rev Oncol Hematol 2016;99:308-23.

13. Norat $T$, Scoccianti C, Boutron-Ruault MC, Anderson A, Berrino F, Cecchini M, et al. European Code against Cancer 4th Edition: Diet and cancer. Cancer Epidemiol 2015;39(Suppl 1):56-66.

14. James EL, Stacey FG, Chapman K, Boyes AW, Burrows T, Girgis A, et al. Impact of a nutrition and physical activity intervention (ENRICH: Exercise and Nutrition Routine Improving Cancer Health) on health behaviors of cancer survivors and carers: a pragmatic randomized controlled trial. BMC Cancer 2015;15:710.

15. Pelser C, Arem H, Pfeiffer RM, Elena JW, Alfano CM, Hollenbeck AR, et al. Prediagnostic lifestyle factors and survival after colon and rectal cancer diagnosis in the National Institutes of Health (NIH)-AARP Diet and Health Study. Cancer 2014;120(10):1540-7.

16. Stacey FG, James EL, Chapman K., Courneya KS, Lubans DR. A systematic review and meta-analysis of social cognitive theory-based physical activity and/or nutrition behavior change interventions for cancer survivors. J Cancer Surviv 2015:9(2);305-38.

17. Van Blarigan EL, Meyerhardt JA. Role of physical activity and diet after colorectal cancer diagnosis. J Clin Oncol 2015;33(16):1825-34.

18. Limon-Miro AT, Lopez-Teros V, Astiazaran-Garcia H. Dietary guidelines for breast cancer patients: A critical review. Adv Nutr 2017;8(4):613-23.

19. Spencer JC, Wheeler SB. A systematic review of motivational interviewing interventions in cancer patients and survivors. Patient Educ Couns 2016;99(7):1099-105.

20. Ellis KR, Janevic MR, Kershaw T, Caldwell CH, Janz NK, Northouse L. Engagement in health-promoting behaviors and patient-caregiver interdependence in dyads facing advanced cancer: an exploratory study. J Behav Med 2017:40(3);506-19.

21. Kushi LH, Doyle C, McCullough M, Rock CL, DemarkWahnefried W, Bandera EV, et al. American Cancer Society 2010 Nutrition and Physical Activity Guidelines Advisory Committee. American Cancer Society Guidelines on nutrition and physical activity for cancer prevention: reducing the risk of cancer with healthy food choices and physical activity. CA Cancer J Clin 2012;62(1):30-67.

22. Key TJ, Schatzkin A, Willett WC, Allen NE, Spencer EA, Travis RC. Diet, nutrition and the prevention of cancer. Public Health Nutr 2004;7(1A):187-200.

23. Kerr J, Anderson C, Lippman SM. Physical activity, sedentary behaviour, diet, and cancer: an update and emerging new evidence. Lancet Oncol 2017;18(8):45771.

24. Baysal A. Beslenme. 12. Baskı. Ankara, Hatiboğlu Yayınevi; 2012.

25. Rock CL, Doyle C, Demark-Wahnefried W, Meyerhardt J, Courneya KS, Schwartz AL, et al. Nutrition and physical activity guidelines for cancer survivors. CA Cancer J Clin 2012;62(4):243-74.

26. World Health Organization. Diet, nutrition and the prevention of chronic diseases: Report of a Joint WHO/ FAO Expert Consultation Vol. 916. Geneva, 2003.

27. Vineis P, Wild CP. Global cancer patterns: causes and prevention. Lancet 2014;383(9916):549-57.

28. Mishra SI, Scherer RW, Snyder C, Geigle P, Gotay C. Are exercise programs effective for improving healthrelated quality of life among cancer survivors? A systematic review and meta-analysis. Oncol Nurs Forum 2014;41(6):326-42.

29. Pamoukdjian F, Bouillet T, Lévy V, Soussan M, Zelek L, Paillaud E. Prevalence and predictive value of pretherapeutic sarcopenia in cancer patients: A systematic review. Clin Nutr 2018;37(4):1101-13.

30. Arends J, Baracos V, Bertz H, Bozzetti F, Calder PC, Deutz NEP, et al. ESPEN expert group recommendations for action against cancer-related malnutrition. Clin Nutr 2017;36(5):1187-96.

31. Anderson AS, Key TJ, Norat T, Scoccianti C, Cecchini M, Berrino F, et al. European Code against Cancer 4th Edition: Obesity, body fatness and cancer. Cancer Epidemiol 2015;39(Suppl 1):34-45.

32. Albuquerque RCR, Baltar VT, Marchioni DML. Breast 
cancer and dietary patterns: a systematic review. Nutr 2017;36(5):1187-96.

33. Sinha R. An epidemiologic approach to studying heterocyclic amines. Mutat Res 2002;506-507:197-204.

34. Stott-Miller M, Neuhouser ML, Stanford JL. Consumption of deep-fried foods and risk of prostate cancer. Prostate 2013;73(9):960-9.

35. Huebner J, Prott FJ, Micke O, Muecke R, Senf B, Dennert $\mathrm{G}$, et al. PRIO (Working Group Prevention and Integrative Oncology - German Cancer Society). Online survey of cancer patients on complementary and alternative medicine. Oncol Res Treat 2014;37(6):304-8.

36. Kale A, Gawande S, Kotwal S. Cancer phytotherapeutics: role for flavonoids at the cellular level. Phytother Res 2008;22(5):567-77.

37. Arends J, Bachmann P, Baracos V, Barthelemy N, Bertz $\mathrm{H}$, Bozzetti F, et al. ESPEN guidelines on nutrition in cancer patients. Clin Nutr 2017;36(1):11-48.

38. Shaffer KM, Kim Y, Llabre MM, Carver CS. Dyadic associations between cancer-related stress and fruit and vegetable consumption among colorectal cancer patients and their family caregivers. J Behav Med 2016;39(1):75-84.

39. Patterson RE, Neuhouser ML, Hedderson MM, Schwartz SM, Standish LJ, Bowen DJ. Changes in diet, physical activity, and supplement use among adults diagnosed with cancer. J Am Diet Assoc 2003;103(3):323-8. 